\title{
DISCLAIMER
}

This report was prepared as an account of work sponsored by an agency of the United States LBL -25992

Government. Neither the United States Government nor any agency thereof, nor any of their employees, makes any warranty, express or implied, or assumes any legal liability or responsibility for the accuracy, completeness, or usefulness of any information, apparatus, product, or DE89 016348 process disclosed, or represents that its use would not infringe privately owned rigints. Reference herein to any specific commeicial product, process, or service by irade name. irademark. nianufaturer, or otherwise does not necessarily constitute or imply its endorsement, recommend"tiv?, or lavoring by the United States Government or any agency thereof. The views and upinions of authors expressed berein do not necessarily state or reflect these of the United States Government or any agency thereof.

\section{Insertion Devices for the Advanced Light Source at LBL}

William Hassenzahl, John Chin, Klaus Halbach, Egon Hoyer, Donald Humphries, Brian Kincaid, and Roland Savoy

\author{
Accelerator and Fusion Research Division \\ Lawrence Berkeley Laboratory \\ 1 Cyclotron Road \\ Berkeley, California 94720
}

Paper presented at the 1989 Particle Accelerator Conference in Chicago, Illinois, March 20 to 23, 1989

This work was supported by the Director, Office of Energy Research, Office of Basic Energy Sciences,

Materials Sciences Division of the U. S. Department of Energy under Contract No. DE-ACO3765F00098 
RSER TION DEVTCES FOR TTIE ADVAVCED LIGHT SOLRCT AT LBL *

W. V. Hassencahl. J. Chin. K. Halbach. E. Hoyet. D. Humprues, B. M. Kuncaid. and R. Savoy

Lawtence Berkeley Laboraloty

Limversiry of Califorma

Berkeley, CA 94720 LSA

Atsraci:

The Advanced Light Source (ALS) at the Lawence Berkeley Laboratory will be the furst of the new generanon of dedicated synctroton light sources to be put into gperatoon. Speadly desgned insermon devices will be required io realize the high brightness photon beams made possible by the low emituance of the electron beam. The complement of inseruon devices on the ALS will inciude undulators with pernods as shor as $3.9 \mathrm{~cm}$ and one or more high field wigglers. The first device to be designed is a $5 \mathrm{~m}$ long, $5 \mathrm{~cm}$ pernod, hybrid undulator. The goal of very high brighmess and high harmonic output imposes unusullly tight wolerances on the magnetic field quality and thus on the mechanical strucme. The derign process. using a genenc strucnure for all undulators, is described.

\section{Intoducrion}

The Advanced Light Souree project at the Lawrence Betreley Laboratory is scheduied for completion in 1993. Based on input from the user community through a eeries of workshops and by letters of interest. we are designing a set of insertion devices (IDs) and associated beam lines that span the spectral range accessible to the ALS. The first devices will have periods of $3.9,5.0,8.0$, and $13.6 \mathrm{~cm}$. The first three are undularors and will be $5.0 \mathrm{~m}$ long: the $13.6 \mathrm{~cm}$ period ID will be a wiggier with a length of $25 \mathrm{~m}$

The intent is to have the major structural compronents of these devices be identical, resulting in a "geacric device", as shown in Fig. 1. The first device to be designed and constructed will be the $5.0 \mathrm{~cm}$ period undulator. US.0. This device was chosen becanse it ean opernte near maimum perfommex at the commivioning gap, which will be $2.4 \mathrm{~cm}$ The support structure, becting beam, and positioning system are ell designed to function comfortably with a maximum magnetic load of $38,000 \mathrm{~kg}$.

\section{Parameress of US.0}

Some paramevers and wolenuces for the first ID. US.O, are given in Table $\mathbf{L}$. These charncteristics were established to fully utitize the potential of the ALS. Each tolennoc in the table is ret by a calculation of its effect on spectral performance. For example, systematic variations of $K$ along the length of the ID, such as those produced by magneric landing, will calse spectral brondening. This effecr on the width of a spectrl harmonic cen be detemined from the iatrinsic or meen width and the effect of error. Expressing all emass in $\%$, the spectinl width is given by:

$$
\sigma_{1 x}=\left(\sigma_{i=2}^{2}+\sigma^{2}\right)^{n}
$$

The intrinsic width consints of contributions from the inserion device and the electron beamis divergence and momenum spread

$$
\sigma_{m}=\left(\sigma_{\Delta p}^{2}+\sigma_{\Delta \varphi}^{2}+\left(\frac{1}{23 n N}\right)^{2}\right)^{12}
$$

where $\mathrm{n}$ is the himonic number, $\mathrm{N}$ is the number of periods, and the fector of 23 converts from FWHM to mis width. Using the sth brumosic bine width as a referesce point, the allowable gap veriation due to menecic landing is found to be $20 \mu \mathrm{m}$ when $\sigma_{\mathrm{e}}=\sigma_{\mathrm{za}}$.

The random error in the pole and block placement and variations in the characteristica of the neodymium-iron (Nd-Fe) block also affect spectinl perfomance. The calloctive effect of ill error is eatublished to limit degradation to less than $3 \mathrm{db}$, i.c. pecral beiliance will be ar least $70 \%$ of that expected from a device with no erron.
Table I LIS.O Paramelers
Penod

Overall Length

Number of Penods

Number of Poles

End Sequence

Maximum Operanor Field

Mimimum Operatonal Grip

Usable Spectrit Harmonucs

Pole Height

Pole Width

A of Blocks per half perion

Block Marerial

Gap Veriation - Single Pole

Gas Veriation - Systemanc:

Single Pole Tilt

Pole Thickness

Pole Thickness Variation

Block Easy axis onimitation $n$
$5.0 \mathrm{~cm}$

$5.0 \mathrm{~m}$

98

197

$-1 / 2+1$

$0.9 \mathrm{~T}$

$1.4 \mathrm{~cm}$

ist 3 rd, \& sh

$11 \mathrm{~cm}$

$8 \mathrm{~cm}$

6

Nd-Fe

50 microns

20 microns

$0.2 \mathrm{mrad}$

$0.88 \mathrm{~cm}$

50 microns

+1.6 degrees

\section{Uamenc Smucnure}

The US.0 will use \& hybnd magneric configuration consisting of Nd-Fe magnetic blocts and vanadium permendur poles. The hybrid is chosen because of several advanlages over the pure current shoct equivalent material (CSEM) derign.

- The field is dominared by the churacteristics of the poles. which can be made very uniform both in rize and mignevic performence.

- The errons in magnetic moments of the blocks can be averiged by sorting the blocks for the poles.

- Errors in the torl magnetic manent of all the blocks on a pole have litule effect on the electron benm or the spectrum becanse they contribute equally to adjacent poles and produce no electron beam stering.

- The peak field at each pole can be tuned by a small amount

- A higher peak field is achievable.

\section{Analysis. fExistine lnsertion Devices}

To aid in the establishment of an enror blerance on the US.0 we have reviewed some of the dat on three insertion devices, the besm line 6 (BL VI) and beam line 10 (BL X) devices at the SSRL (1-3), and the TOK device at the NSLS (4). One of the sigmificant results from this andysis is that the major field errose are in the region between the poles. This can be reen in Fig. 2, which shows the residun magnetic field errors song the ainl direction after the allowed sparial harmonics are removed using nonlines lear squers fiting. The dushed lines show the centers of the poles. The source of these emors is not complenly known at present, but sevend pastibilities hrve been explored. Thene include: misibignment of the mignetic moment of one ar more blocks. which would lest to magnetic chrige sheet on the surface facing the electrod beam; a mismatch between adjacent blocks, which would lead to a retical sheet of mignetic charge directy above the electon beam; and a vertical mishigament of the Hocks. which would lead to an intene bur nurrow chroge theet jurt above the electron beam

In addition to the andyris of these devices, the effect of selectively pairing pole assemblies with known field devietion ba been soudied. The fOK wigeler, as initivlly aseembled, had random field erross in pole field strength of about 0.5\%. By selectively pairing poles with high or low strengths the effective crior was reduced, yielding an effective error of about $0.1 \%$ based on calculated electron onjectory and calculated and observed apectrel peformince 


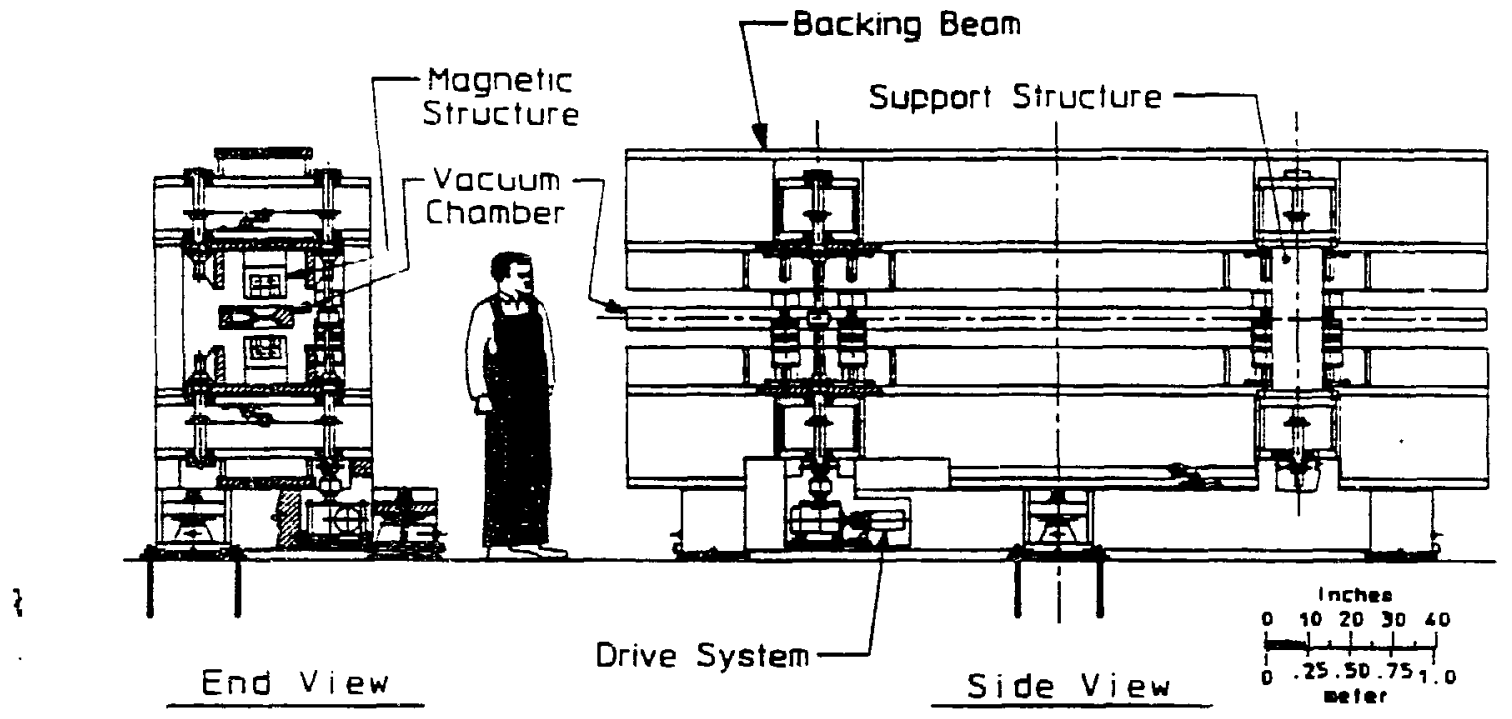

Fig. 1. The generic mechnical sucture for the LBL Advanced Light Source insertion Devicer. The Soucture is $5.0 \mathrm{~m}$ long and is designed to accommodare mignetic louds op to $38,000 \mathrm{~kg}$ with soceptable deflections.

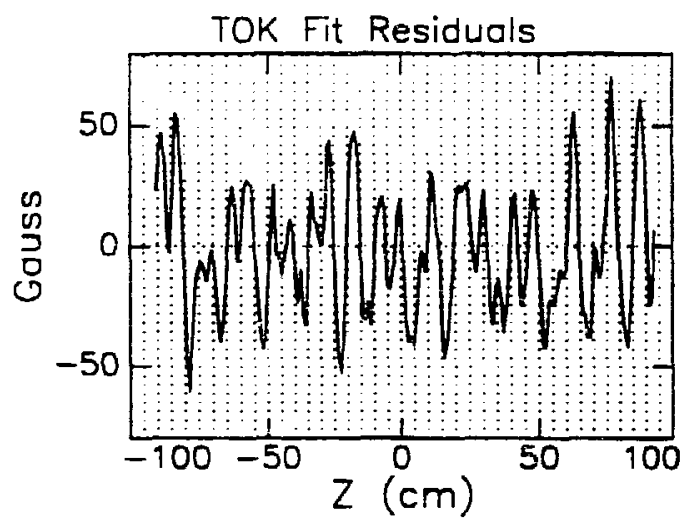

Fig. 2. Magnetic field reviduals in the Transverse Optical Klytron at the NSLS. These are the the fields that remain after removing spatial harmonics detrrmined in a non linear least squares fourier analyas of the field. The domed lines show the centers of the poles. The field errors wend to be greater in the regions berween poles than on the poles.

\section{Mamtitic Configmation}

The periodic magnetic etructure consisting of Nd-Fe blocks and vanadium permendur poles that is proposed for US.0 is shown in Fig. 3. The configuration consists of a rectangular pole and an array of $6 \mathrm{Nd}$-Fe blocks. The principal objective of the design effort wes to develop a magnetically well behaved structure thar maximizes $B_{m}$ (as defined below) for midplane fields. The design approach utilizes Halbach's three dimensional (3-D) Hybrid Theory and two dimensional (2-D) mocieling with PANDIRA(5).

PANDIRA allows convenient 2-D modeling of anirotopic mitierials. These materials are defined by the reminent and coerrive field intercepts of the linear B-H curve associated with the Nd-Fe along with its easy axis orientation angle. The vanidium permendur is deacribed by a non-liner B-H curve based on myasured data.

The 2-D models are used to oprinize thi: pole thickness, to provide detriled information about magnetic betavior, and to provio's flox infarmation for the 3-D calculation. The sansverse width of the pole is determined by extermal considerarions such as limits on $\mathrm{dB}_{\mathrm{f}} / \mathrm{te}$, ( $\mathrm{x}$ is the transverse - horizontal direcoon) and scaling from other devices. The set back of the Nd.Fe above the poie face is detemined by vacuum chamber and assembly toletance constraints.
To perform the 3-D calculation, pole flux is sepunted into a direct and an indirect llax, which are further separted into uniform and non-uriform components. The direct flux comes from the NdFe and establishes the pole's sealar potential. The indirect flux. which can be calculated, resulu from this scalar potential and is composed of convibutions from all surfeces of the pole.

An overtung of Nd-Fe at the cop and sides of the pole is ured to achieve desired performence and so optimize the quantity of Nd-Fe ased in the struchere. This overhang contributes to the 'direct' flux and causes on increase in the scaler potentid of the pote. The find dimentions result from balancing the direct and indirect fluxes. where overtung dimensions and pole beight are edjusted to achieve dexired performance with a minimil volume of Nd-Fe.

The spatial humonics in the fields af the midplane, in the region of the electron beam, exe exmined by expressing the field in a Fourier series, where the periodic structure is assumed to be infinitely long and wide. The epproprivte expession convining only those composents allowed by symmetry is:

$$
\mathbf{B}(z)=\sum_{i=1}^{-} b_{z+1} \cos \{(2 i+1) k z) \cosh ((2 j+1) k y)
$$

Where $k=2 \pi / \lambda_{\mathrm{L}}, \lambda_{\mathrm{I}}$, is the undulutor period, and $b_{2 j+1}=$ $\mathrm{B}_{2 \mathrm{i}+1 / B 1}$ is the nommlized amplitude of the $2 \mathrm{i}+1$ freld component. $B_{1}$ is the amplitude of the fundamental. The volue of $B_{m}$ thut is maximized to echieve peat performance is defined as:

$$
\left.B_{n=}^{2}=\sum_{i=1}^{\infty}\left(B_{2+1} J(2 i+1)\right)^{2}=B_{i=1}^{2} \sum_{2+\nu}^{\infty}(2 i+1)\right)^{2}
$$

For $\lambda_{u}=5.0 \mathrm{~cm}$ the thind harmoric (b3) at the midpinac for a paie thickness of $8.8 \mathrm{~mm}$ is less than $5 \%$ of the fundingental and higher harmonics are negligible, b5<1\% and b7<0.25\%). The percentage of thind hormonic is mximum at the design $84 p$ of $1.4 \mathrm{~cm}$ and decreases es the gap increases. This hamonic sould be reduced slightly if it were not necessary to have a $1 \mathrm{~mm}$ chamfer, which is included to reduce the effects of caturation.

\section{Insertion Device Mechanical Design}

Figure 1 shows the major subsystems, magnetic structure. suppor struchure, drive system and vacuum system for the proposed $5 \mathrm{~m}$ long U5.0. The design philosophy for the initial complement of insertion devices is loward a geneaic insertion device design to reduce enginesring and fabrication costs and for eusjer maintainability: Undulator and wiggler components that will te similar include the backing beams, support strectures, drive systems. vacuum chamibers. and pumping systems. 


\section{Magneac Sucruse}

Figures 1 and 3 show the proposed U5.0 magnete structure. wheh includes:

Haif penod pole assemblies consisung of an dumnum keeper. a vanadium permendur pole $(8 \mathrm{~cm}$ mide $\times 12 \mathrm{~cm}$ hugh $\times 0.88 \mathrm{~cm}$ thuck). Nd-Fe blocks $(6.8 \mathrm{~cm} \times 3.87 \mathrm{~cm} \times$ $1.62 \mathrm{~cm}$ in the onentation direcoon). Pole assembly fabricanon is planned to be smular to thas used on the BL VI and BL $X$ wiggler poies(1,2).

Pole assembly mouns fabricated from ig plate aluminum for mounting and accurately positioning approximately 20 pole assemblies each. Each pole assembly mount is in turn binematically mounted onto a backing beam

- Sieel backing beams bold the migneac structure components and provide magnetic shielding. Thewe $5 \mathrm{~m}$ long berms (2.5 $\mathrm{m}$ for the wiggler) are rigid, with a deep, $81 \mathrm{~cm}$ web and a $89 \mathrm{~cm}$ wide flange to minimize systematic gap variations. which cause a loss in spectinl periormence.

- Sets of rotators, for nulling the field integral, similar to those used on the BL VI undulawr, are plamed.(3)

- Tuning studs and anxiliary coils have been considered and will be designed and implemened if required.

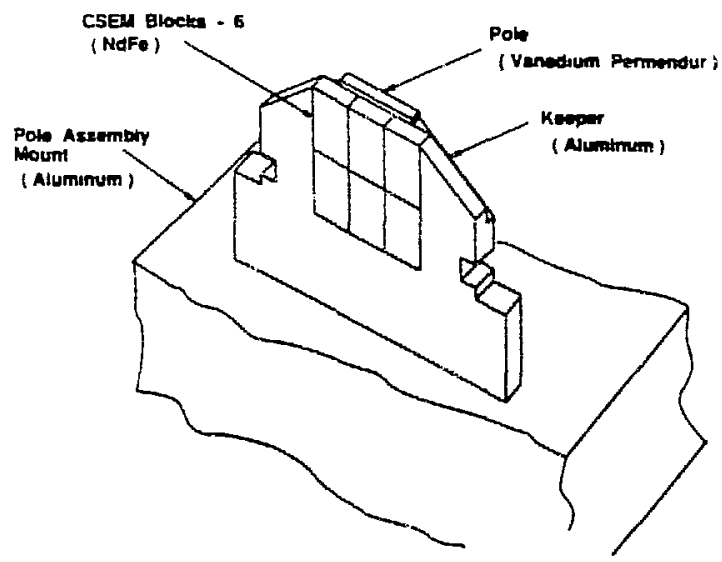

Fig. 3. The pole assembly for the US.0 insertion device. Shown are the Vanndium Permeaduc pole, the aix Nd-Fe blocks, and the sluminum keoper as atrached io the Assembly mount

\section{Suppous Struciure}

Two types of supponi strecture, 4-oont and C-frame, ware evaluated in the process of derigning the US.0. The 4-post suppont structure whs selected becunse of the following advantuges:

- Grearer bimel woll was cleance.

- Lear gap deflection dee bo a hare rigid matucture.

- No pole rotucion (tilt) due no symmetical londing

- Better access for arsembly of components.

Advantager of the C-frums included easice vactomm chnmber installation and the pastibility of using extenal magetic merrextrent equipment

The 4-past design congien of a rigid bare with: 3 linematic floor mouns and aligamat wenblies, 4 horizonol smonbers that pass through the 2 buclang beam, and 4 vertical posts. This moduls derign provides for eary arembly and future servicing. The 4 horizontel members pas through the backing besms, which allows the wocure in fit within $2.4 \mathrm{~m}$ high tumnel.

\section{Doive System}

The trive aystam, which will be componer controlled, conists of a motor, a drive texin, an sbalnte encoder and a contrilles with diginal readont The moter in the drive trin dives a 30:1 reduction

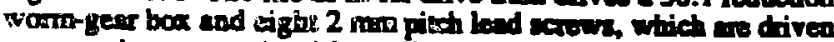

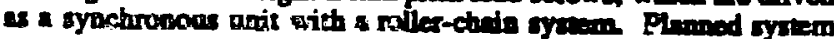

capability includes a mamum incremental mouon of the magneac gap of 0.1 mactons. maxumum gap moson of $2 \mathrm{~mm} / \mathrm{sec}$ cond. and operang to fuli gap. $21.6 \mathrm{~cm}$, in less than 2 minutes. To enhance the responsiveness of the dnve system to small motions. nonisnear compensaung spnng system has been designed to follow the vananon in magneac load with gap. This design consists of several sets of different sizes of bellevill = washers and a compression coil spnng stacked together into one assembly.

\section{Vacuum Sysiem}

The vacuum chamber design. Fig. 4, show a rigid. two-piece, welded chamber of either 5083 H321 Aluminum or 316 L SS, similar in construction to the $B L X$ vacuum chamber. Materid selection will be determined on the baris of achievable fabrication tolsrences, ratistion shielding effectiveness for the permanent magnet material. and fatrication method of the clearing electrode. Chumber intermal dimenrions are 3 vertical aperture of $10 \mathrm{~mm}$ and horizontal apernure of $217 \mathrm{~mm}$. The design allow for a minimum manet ges of $14 \mathrm{~mm}$ (15 mm if derring electrodes are required) through the use of thin sections, $0.75 \mathrm{~mm}$ thick, as the pole locetions. The borizontal aperture is large to allow the bend mignet radiation to puss through the insertion device region and be absorbed downstream. The enlarged chamber area will aid horizontal vecuum conductunce.

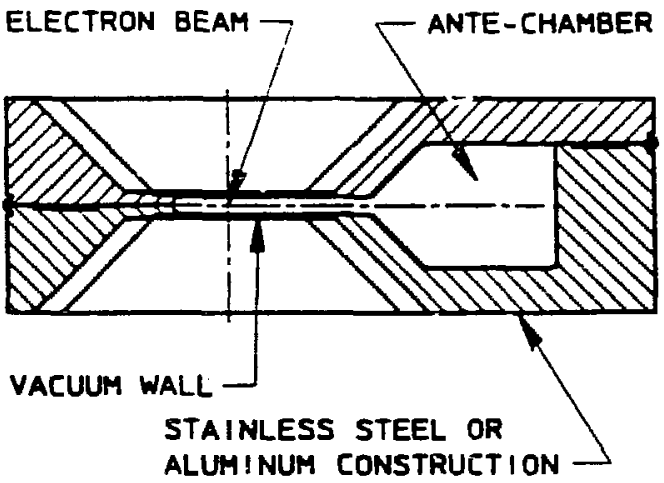

Fig. 4. The vacuum chumber for the US.O.

\section{Refinences}

[1] E. Hoyer et al., The Beam Line VI REC-Hybrid Wiggler For SSRL, IEEE Trank NS-30, 3118, (1983).

[2] E. Hoyer, et al.,The Beam Line X Nd-Fe-Stoel Hytrid Wiggler For SSRL, IEEE Canlog No. 87 CH 2387-9, 1508 (1987)

[3] K. Halbach et al., A Permenent Magnet Undulator For Spenr, IEEE Trans. Noci. Sci, NS-28, 3136 (1981).

[4] R.R. Freemun and B.M. Kincid, "Production of Colterent XUV and Soft X-rays U ing a Traneverse Optical Klyetroe," Later Techriques in the Extreme Ulmuviolet S.E. Herris and T.B. Lucutorio, ads. (Am lnit of Physica, New Yark, 1984).

[5] PANDIRA is an improved verion of POISSON, which allows colution of permanent magnet and residual field poblems. POISSON in tum is an improved verion of TRTM (A.M. Winslow, J. Computer Phyz. 1. 149, (1967)), developed by K. Halbach et al. 